\title{
Change/Interchange in Virtual Learning Environments: Aesthetic Activity and Video Letters Produced Between Brazil and U.S. Students
}

\section{Trocas/Intercâmbios em um Ambiente Virtual de Aprendizagem: atividade estética e videocartas produzidas entre estudantes do Brasil e Estados Unidos}

\author{
Adetty Pérez Miles \\ Katyuscia Sosnowski \\ Maria Cristina Villanova Biasuz
}

\begin{abstract}
We analyze in this text, under a Bakhtinian perspective, dialogues produced and shared between undergraduate licensure students in visual studies education from two different countries, Brazil and the United States. The discussions were created for Aprendi 2.0: (In) Connection with the 9th Mercosur Biennial. This project aimed to promote online intercultural exchanges, which were integrated into the students' curriculum. Among our analysis, it was possible to observe that the utterances produced by the students through video letters, promoted a dialogical and responsive encounter among them. We invited multiple voices into the text, which arose from video letters, images, and interactions on a virtual learning environment. The objective of the research was to understand from an ethic-aesthetic perspective, the processes of subjectivity formation of the involved participants that supported collaborative authorship in online environments.

Keywords: Online Exchange. Video Letters. Authorship. Pre-service Art teacher. Bakthin.
\end{abstract}

Resumo: Analisamos neste texto, sob uma perspectiva bakhtiniana, diálogos verbais e visuais produzidos e compartilhados entre alunos de licenciatura em artes visuais de dois países, Brasil e Estados Unidos. Nosso campo de análise foram as discussões criadas no Projeto AprenDi 2.0: em conexão com a 9a Bienal do Mercosul, Porto Alegre. Este projeto teve como objetivo promover um intercâmbio intercultural online integrado no currículo dos alunos. Em nossa análise, foi possível observar que as videocartas produzidas pelos estudantes promoveram a autoria coletiva em um processo dialógico. As múltiplas vozes que surgiram a partir de videocartas, imagens e as interações no ambiente virtual de aprendizagem contribuíram para a compreensão do conceito de enunciado em Bakhtin. O objetivo da pesquisa foi entender a autoria colaborativa a partir de uma perspectiva ético-estético, e os processos de formação da subjetividade dos participantes envolvidos.

Palavras-chave: Intercâmbio online. Videocartas. Autoria. Arte/educador. Bakthin.

PÉREZ MILES, Adetty; SOSNOWSKI, Katyuscia; BIASUZ, Maria Cristina Villanova. Change/Interchange in Virtual Learning Environments: Aesthetic Activity and Video Letters Produced Between Brazil and U.S Students. Informática na Educação: teoria e prática, Porto Alegre, v. 19 n. 1, p. 29-40, jan./maio 2016. 


\section{Aims: AprenDi 2.0 Project: (In) Connection with the 9th Mercosur Biennial}

In the ambit of being, human freedom is only relative and deceptive. But, in the order of meaning, it is, in principle, absolute, since the meaning arises from the encounter of two subjects, and this encounter resumes eternally. The meaning is the freedom and the interpretation is its exercise (BAKHTIN, 2011, p. xxxii).

In 2014, Jean Luc Godard sent a video letter instead of appearing in person at the Cannes Film Festival in France. Godard's Letter in Motion, and collaborative projects such as Global Video Letters, and Global Art Exchange ${ }^{1}$, the latter in the field art education, use new media as a way of presenting, exchanging, and dialoguing with people geographically distant. Our investigation focus is AprenDi 2.0: (In)connection with the 9th Mercosur Biennial ${ }^{2}$ (from now on shortened to AprenDi 2.0) - a project that supports intercultural online exchanges between geographically distant collaborators, through visual studies education, the creation of video letters, and virtual learning environment (VLE).

AprenDi 2.0 was developed in 2013 as a part of an intercultural exchange between licensure art education students in two different countries, Brazil and The United States. Professor Maria Cristina V. Biazus in computation and education, and Ph.D. candidate Katyuscia Sosnowski at Universidade Federal do Rio Grande do Sul (UFRGS) in Brazil, and professor Adetty Pérez de Miles, in art education at the University of North Texas (UNT) in the U.S. guided the collaboration. The objective of the project, to echo the epigraph, was ontological, to explore how meaning between prospective art educators arose from their encounters, and how they interpreted and regenerated these exchanges in ways that were meaningful to their lives as artists and novice educators. Moreover, the aim of the project was to promote mutual understanding of contemporary art available in the context of the two groups, highlighting the international Mercosur Biennial in Brazil-an event with focus on international and local audiences, which is committed to art and pedagogical endeavors, such as teacher online training, workshops, lectures, and opportunities for educators and students to participate in art events connected to the biennial (CAMNITZER, 2006).

\section{Background and Methods: Video Letters}

In this text, our focus is the students' dialogues, as seen and heard in 12 student-produced video letters: one collective Brazilian video letter and 11 individual video letters by U.S. students. We highlight that this investigation is part of a wider study, and it is part of a field experimentation in which the participants speak different languages and engage in dialogue using Internet translation tools and visual language. In order to support the project, we used Moodle, a free and open source

\footnotetext{
${ }_{1}$ Available at: <http://globalvideoletters.org > and <http://www.oneworldclassrooms.org>. Accessed: 04 Jun 2014

2 Available at: <aprendi20.org>. Acessed: 30 Jul 2015.
} 
virtual learning environment (VLE). For the initial collaboration, each group (Brazilian and U.S. students), created five-minute video letters to introduce themselves, their university, their city, their culture, and the geography of their city to the partner group. In order to help bridge the communication distance implied in the foreign language between the authors, the participants requested the inclusion of subtitles and credits in both languages, Portuguese and English.

Figure 1 - Print screen of the moodle platform, 2013.

Module 1 - Dialogues about each of us - Aug 19 to Sep 16, 2013

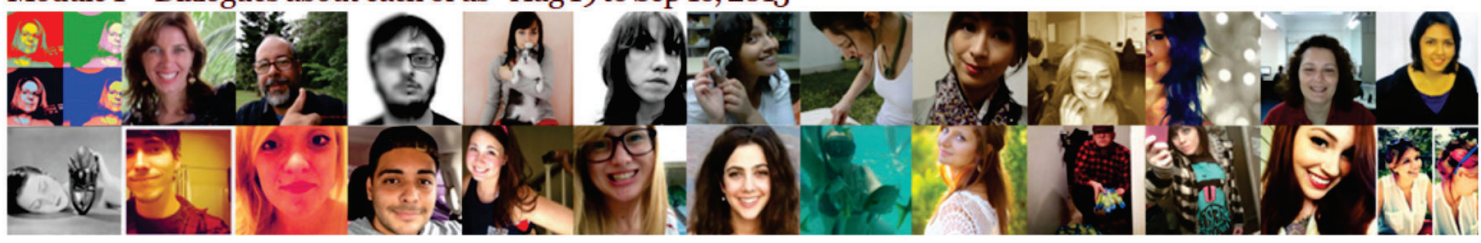

Sobre o modulo 1/ About Module 1

Questionário / Questionary for everybody

Discutindo sobre o UFRGS vídeo \#1/ Discussing about UFRGS video \#1

Discutindo sobre o UNT video \#1/ Discussing about UNT video \#1

UFRGS:Bastidores/ Making of by UFRGS video \#1

UNT : Cristina's introductory video for UNT students

Source: moodle plataform print screen

All the video letters were published on the Internet, in channels such as YouTube and Vimeo, and they were linked back to the Moodle. The professors/researchers established the forums on the Moodle platform, with the aim of encouraging dialogue and deepening themes and issues that arose from the videos and text.

The activities were developed in asynchronous meetings, considering the class schedules and time zone differences between the groups as well as the unfamiliarity of the language spoken by the partner group. Our objective as professors/mediators was to introduce a proposal to create video letters, contextualizing our starting point and the goals we intended to reach. We noted:

Images have much to say, but they don't say everything! Look for balance between the visual and the writing in the elaboration of the video letters. The images must come with the written language, so that they can be perceived as more than just a reflection of our imagination or creativity. For us, to dialogue in an experience of exchange, it is important that the sensations and perceptions permeate our interactions as a way to say something about who we are, and what we care about. The idea is that videos or photos are accompanied with a phrase or narration in English/Portuguese, expressing our focus on our images. Thus expanding the vision on the production itself. This reinforces the possibility of utilization of the images as a starting point for our dialogue. (PÉREZ MILES; SOSNOWSKI, 2013, s/p). 
This statement was proposed to trigger the video letter production process for both groups. The professors created a forum called Our Community for both groups to publish images and the making of the video letters production process, and two forums for discussions after the video letters were received. The mediations, proposals, and informative texts on the platform were created in collaboration among the professors and were, always aiming for clarity and for translation appropriate to each group and to culture. Communication between professors was maintained via Skype and e-mail. We understood the video letters and online forums as the possibility of verbal-audio-visual dialogue conducive to cultural and educational interchange. The visual resources used in the statements of the video letters aimed to create meaning for the interlocutor, who by immersing him or herself in the discourse(s), would search for meaningful dialogue and interaction with collaborating partners.

\section{Theoretical-Methodological Perspectives: Aesthetics of Being, Author- Person and Author-Creator}

Our analysis is grounded on the interactional thinking of Mikhail Bakhtin (1895-1975), regarding concepts such as the utterance and authorship. From a Bakhtinian perspective, every subject, author, or artist, considers, in her or his creation process, an interlocutor, the other to whom the utterance of the work is intended. This Other, nevertheless, and the listening that might happen, are but potentially possible. According to Bakhtin (2011), there are two author beings, the author-person (the artist, the writer) and the author-creator (the person that exercises the aesthetic function in the work), distinct beings in the same discursive production: the author creator, element of the work, and the author-person, component of life. Dialogic communication is therefore, dynamic and relational. Pérez de Miles (2011) remarks that Bakhtin and Freire's theories suggest that:

Voice is accomplished only when participants in dialogue can produce, rather than passively repeat, discourses. Voice is accomplished when participants play an active role in the creation of the discourse and co-author the text under consideration. To reiterate, for Bakhtin, language is dynamic and relational, imbued with new meaning when repeated in new contexts. (PÉREZ MILES, 2011, p. 15).

We can say that in our intercultural action, the students accepted to become authors when they broke the silence and accepted the challenge to dialogue. Both groups had no prior knowledge of the language of the foreign group, however, they had the determination and wanted to learn more about each other, and what the other had to say about their community and about their art.

According to Bakhtin, the fundamental element for language analysis is the excess of seeing, the image, the portrait, the visual and verbal self-portrait, that is, one's own representation, the moment when the author becomes the person. When $\mathrm{s} /$ he responsively lets the self be affected by the narratives of others, and to approach their stories, life, and their artistic expressions in an aesthetic experience, are acts that can help us understand these narratives and expressions, as well as constitute us as subjects in our own experiences and contexts. 


\section{Theoretical-Methodological Perspectives and Authorship}

Our theoretical-methodological perspective is grounded on a Bakhtinian ethical-aesthetic paradigm, proposed by Amorim (2004) and Axt (2011), which pervade ways of being, history, beliefs, and values unachievable on its totality. This perspective considers the subject of research and the authors of the theoretical background as partners in experimentation and in writing. The whole process is dialogue. The researchers, i.e., professors and students make use of statements coming from all directions, in an attempt to organize a new text, challenging themselves to propose new and countless dialogues with other new interlocutors. Furthermore, our thoughts and beliefs are crossed by many voices, arising from different fields such as philosophy, social sciences, critical theory, art education and language studies. The encounter with the Other is chance to encounter one's self. In Bakhtin's words,

Everything that concerns me, beginning with my name, comes from the external world into my consciousness by the mouth of others (my mother etc.), with their intonation, in its emotional evaluative tone. At first, I become aware of myself through the others: from them I receive the words, the forms, the tone for the formation of the first notion of myself. (BAKHTIN, 2011, p. 374).

Our participation, online and in person, in the mediation process, was based on these assumptions, as stated above. In the analysis phase of our work, we revisited the data registered on Moodle, which took us to the first interpretations. As a platform, Moodle gives us a misleading impression of full control, because it has the characteristic of quantitatively reporting posts, schedules, amount and types of access of all the involved and registered participants. The data certifies that there was some kind of interaction with the VLE/Moodle. However, these numbers do not tell of the qualities of interactions that matter to this research: verbal-audio-visual dialogues produced between the subjects involved in the process.

\section{UFRGS-Brazil: Video Letters: Dialogic Utterances}

The utterances of the authors-creators expressed on the video letter from the Brazilian group ${ }^{3}$ and on the 11 video letters ${ }^{4}$ from the USA group, and the posts registered in the Moodle forums after the video letters were published, are the object of our analysis. We are interested in the processes of subjectivation that involve the ways by which notions of identification are produced, i.e., who we think we are and how we live in the world. We looked for these

\footnotetext{
${ }^{3}$ Available at: <https://www.youtube.com/watch?v=LI2eIXdaYFg>. Accessed: 2 Jun 2014.

${ }^{4}$ Available at: <https://www.youtube.com/playlist?list=PL3EtZOdXjuVG2OdcD4mFHcqdTbk6s-Pfr>. Accessed 6 Aug 2014.
} 
Figure 2 - Frames from UFRGS video letter, 2013.

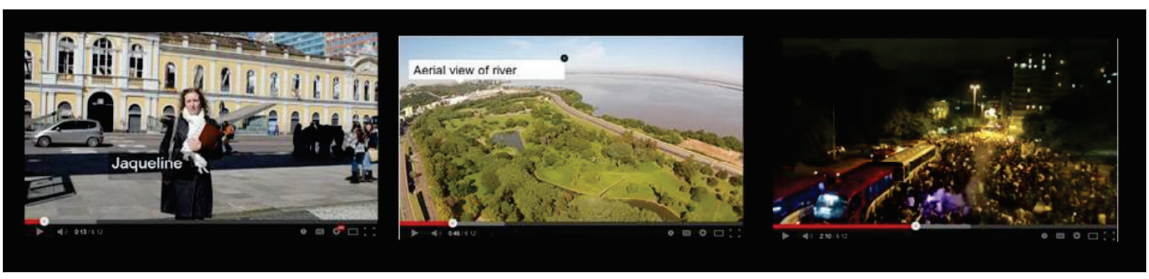

Source: UFRGS video letter

Processes expressed in the verbal-audio-visual statements, understood in this text as video letters and post in forums produced by the author-creator participants. Understanding that: "To work with the dialogical presupposition in research is [...] to consider multiple voices, in a tense relationship between them" (AXT, 2008, p. 98). Thusly, "[...] both the voices of the experimentation participants, as well as the voices of the theoretical background voices and the researcher-author, within a wider relationship of confrontation between the monological and dialogical force fields [...]" (AXT, 2008, p. 98).

As one of the professor who followed the production of the video letter from the UFRGS-Brazil group in person, I could perceive some dialogic tensions/confrontations (visible as disagreements) among the group. The collective video letter was planned and discussed by the students, in person, in the classroom. Two of the students, Julia and Jeanne ${ }^{5}$ had professional technical knowledge about video editing, thus, they volunteered to do the final editing. The Brazilian students planned external footage and chose different scenarios in the city of Porto Alegre to create their scenes in order to compose the video narrative. Two of the students decided to produce the text that was going to be narrated in Portuguese, and chose to highlight a gaucho - a local cowboy accent. Another student was assigned with producing the English subtitles for the video. Differences over political positions inside the UFRGS-Brazil group became clear during the final editing of the video letter, when disagreements came up about the message that the video should convey. When the video letter from UFRGS was ready, two students expressed their disagreements with the final result.

Julia argued that, the video images were not in dialogue with the narrated text. Using a positive tone, Julia defended the idea that it was important to create a professional looking video that put together existing footage from popular videos about the city, with images available on the Internet, some of which included scenes depicting soccer games between the two most popular local teams. Moreover, she supervised the video clips filmed by the group itself, and tried to replicate visual language found in several of these videos - like the sequence of participants that walk towards the camera. Meanwhile, Elias, another student, defended a concept that he saw as more closely related to video art, including documentary-style photographic intakes with information about the size of the population, and the weather, which is often localized geographically. The group divided the tasks for creating the video. Elias was charged with creating the narration text for the video letter, and Julia was charged with editing. When they gathered the material together a dispute arose over the authorship of the video, not the author's signature, but a dispute over the conceptual content of

\footnotetext{
${ }^{5}$ The names of the participants were replaced by pseudonyms in order to protect their identity.
} 
the video, in other words, over who would contribute the most to the major intellectual and visual/ aesthetic ideas of the video letters.

After this exchange, Elias left the classroom and sent me the following e-mail: I was very disappointed with this group of professor/artist aspirants that do not want to position themselves as artist-educators, and find it relevant to talk about soccer in a video that has everything to do with a piece that has the potential to become an artwork. In the end, the only way that I can participate is like this, via Moodle. From this point on, Elias stopped attending classes, and gave up participating on the online platform. The course was a blended course that required face-to-face and online participation. Unfortunately, Elias officially withdrew from the course.

The creative work consists in a struggle among statements to be inscribed in the world.

Bakhtin explained that in dialogue in the classical form of discursive communication, "[...] each reply, as brief as it may be, has a specific conclusiveness by expressing a certain position of the speaker that demands an answer, related to which it may assume a responsive position [...]" (BAKHTIN, 2011, p. 275). Elias demanded a responsive answer, and although he withdrew from the course his words, continued to echo in the classroom. One of the responses to Elias's position that was particularly productive was Juliane's (UNT-USA) interrogation of the video's technical and formal qualities, and the choices that Brazilian students made in regards to content. Her queries opened up conversations among the students (although Elias was no longer in the class) that created opportunities to talk openly about issues in regards to authorship, artists intent, and the entanglement, ambivalence, and messiness that happens when multiple voices collide in dialogic tensions. In Bakhtin's words, "[...] anything that does not answer a question is devoid of sense [...]" (BAKHTIN, 2011, p. 381). The student sought to make sense, the dialogue among the student flowed through utterances that oscillated between answers and interrogations, asking in this way for further continuations of dialogic and aesthetic flows.

In sum, the video letters from the UFRGS-Brazil group display a contemporary style of video production. Image speed and transition effects, enabled by contemporary computing programs, were used across the 5:12 minutes of the video. The appropriation of other videos already published on the Internet became a part of the composition, of the aesthetics of the new work. The authors-creators from UFRGS-Brazil chose to introduce on their video letter, images about popular manifestations that occurred in the city of Porto Alegre. They presented a new image of the world that is in a new plane of existence that reverberate from the ethic to the aesthetic plane, insofar as they chose images that affected them and the world around them.

\section{Authorship: The Centripetal and Centrifugal Forces of Appropriation}

The video letter created by UFRGS-Brazil students are examples of the culture of dialogism and appropriation, which are co-authored spaces in which images, sounds, and information are seen as available to anyone who wants to manipulate them. Bourriaud (2009) helps us to understand the contemporary style of this type of verbal-audio-visual production, when he writes about the use of new forms, which began to appear in the 1980's and 1990's. With the expansion of computers, 
and the possibility of sampling and mixing of sounds, and appropriation of images, the use and manipulating of aesthetic forms were widened. The point is, that in contemporary times, "[...] the remixer became more important than the instrumentalists, the rave, more exciting than a concert [...]" (BOURRIAUD, 2009, p. 35). This is the type of authorship and co-authorship that Bakhtin theorized though his theory of dialogic communication. Every utterance is internally dialogic; it not only expresses the particular position held by the speaker, communicates some particular objective content, but also always responds to the previous context and anticipates the listener's response. The video letters created by UFRGS-Brazil students are examples of the culture of dialogic authorship and appropriation. The access and the possibilities of appropriation of images promoted by Internet and digital technologies, create possibilities and difficulties for the way authorship is established and negotiated (e.g., the dialogic tensions between Julia and Elias).

We understand our students' contemporary productions (re-mixes and hybrid works) as dialogical and unfinished works. The author/artist, with the help of the digital tools, narrates multiple times in the multiple voices that result from the images, sounds and texts previously produced. For instance,

Bakhtin's theory of dialogism posits that meaning is created and lived in the interstices of different texts, in authoring and co-authoring, in the threshold of the dialogic relationship between the speaker and the listener, the writer and the reader, the artist and the art interlocutor. (PÉREZ MILES, 2011, p. 55)

The posts by students in the Moodle and in conceptual ideas in the video letters may be considered as processes of authorship and co-authorship. These creations parallel cyber culture, whereby the original post and comments posted by blog readers are considered as much a part of the work as the original text.

The post below shows some questions that resulted from watching the video letters, for instance, Juliane a student at UNT in the U.S. stated the following:

I really enjoyed watching the images of your city and reading the carefully prepared text that introduced your country to us. It was clear that you were very thoughtful in your inclusion of certain information and images, particularly, about the protests in relation to the World Cup Football event and difficulties with traffic. You could have only showed us positive aspects of your city, but you chose to include some of your "concern, anxiety and uncertainties." This is a very realistic view of your city and the environment in which you are working, and as you say, a motivating factor in artistic production. (Juliane, UNT, 2013)

We recognize the students' video letters as creative events. As works of art, the qualities of video letters are that they are non-systematizable, singular, responsive, and deserve participatory answers (Emerson, 2003). According to the Emerson (2003), the condition that makes all of these 
attributes possible is the exteriority. The finished and published video letters are not yet ready, as they are created to demand consciousness and authorship from the interlocutors.

\section{UNT-USA Video Letters: Dialogic Resonances}

The group from UNT in the U.S. used the strategy of production of individual video letters. Among the 11 video letters published and addressed to the UFRGS-Brazil group, it is possible to categorize some constants such as: the town square; the university campus; art spaces and public art works; the use of Google Maps images, personal narration about collections and hobbies, and subtitles and songs chosen to be included in the videos. The narrative constructions are nevertheless differentiated in 5 of 11 video letters. In these videos, the students start a free-style narration in front of the webcam of their computer and then take the viewing partners for a tour around their home and their town. Each student enters a position as a second person, as an author-creator, as another in relation to the production itself. The video letters are works with a kind of openness, an invitation to an answer, which will perhaps invite in its turn, another response. Bakhtin (2011) notes that it is impossible to make decisions without considering other voices. We can thus understand that authors and coauthors produce more than works: they create "[...] dialogic resonances [...]" (BAKHTIN, 2011, p. 300).

The students sought to create social resonances, so that the video would make sense for the distant Other, in this case the UFRGS-Brazilian students.

Figure 3 - Frames of the video letters of UNT 2013.

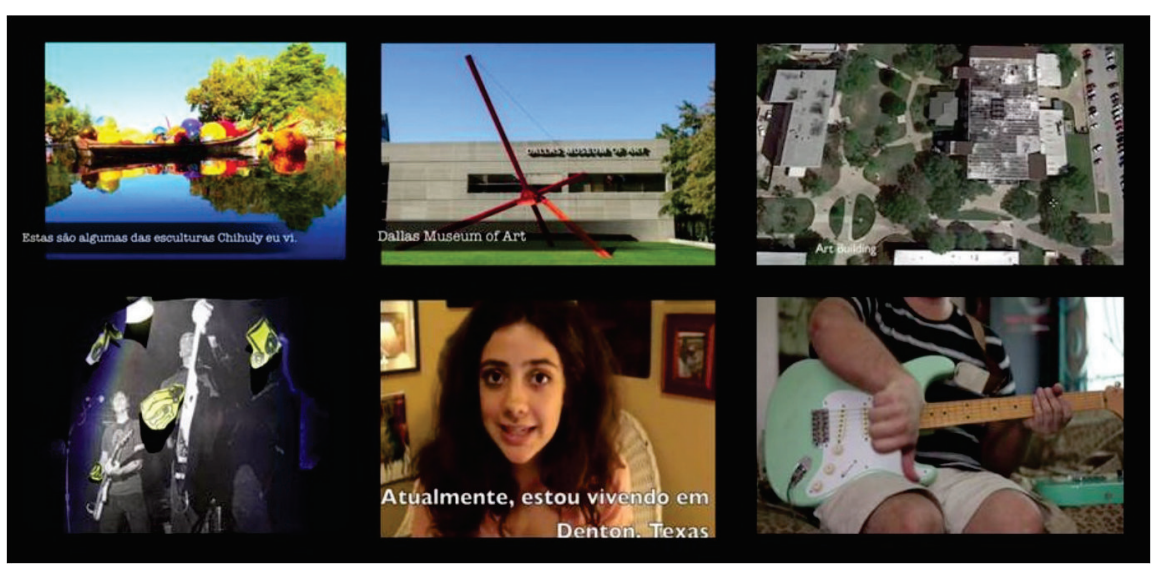

Source: UNT video letters.

This cycle of invitations and answers could be understood as Bakhtin's concept of resonances. Invitations and answers occurred in the video letters, and later as discussions in the forum. The video letters are open by the multiplicity of meanings of readings and interpretations. For example, Valter (UFRGS-Brazil) wrote to Alana (UNT-USA) and commented: 
Alana (UNT-USA) responded the following:

Your video is special, mainly because you have exposed your concerns, which are not so different from ours in relation to our teaching profession here. In fact, all teachers (in free public schools, which are the majority) suffer from low wages, violence in schools, and lack of adequate infrastructure. Furthermore, we, the teachers, also suffer from the devaluation of our disciplines over other fields of study, that is, we suffer the same ills as you. One bright spot that we have here is that the federal government recently passed a law, mandating the teaching of Visual Arts, Theatre, Music and Dance, but unlike the U.S. (I believe), here laws do not work in practice. We have to fight hard to get them fulfilled. I'm astounded by the account of the crisis in education in your country. And I wonder how the elementary school? Do you have free public schools? ... and other things that you can tell me. I was very interested in your vision and reflection on our area

The authors of these statements assume an active and evaluative position in a concrete situation of communication, which renders an expressive intonation to the utterance. "Meaning is reviewed in each new context, according to Bakhtin's theoretical approach, in an infinite and endless dialogue between author subject and reader subject. This is a true process of co-creation, or co-authorship, in which no meaning dies [...]" (BIAZUS, 2001, p. 60). The content in the utterance is the network of relationships, which axiologically transcends the material. It is that which is beyond the work as a material object, to give place to work as an aesthetic object, object rooted in history and culture, permeated by meanings and values.

Further, the textual creation set out by the video letters can be understood as a construction of meaning, through utterances such as:

Kristy (UFRGS-Brazil): Thank you for the bike ride! [...] Your video made me think about the potential of different things happening at the same place. Here at our University Campus it is fragmented. The Arts (Music and Visual Arts) occupy a building outside the Central Campus. But in the Central Campus, there are two small rooms for ceramic and sculpture. [...]. Our common spaces are limited, and at the Institute of Arts, there are just small halls connecting the classrooms. [...]. The concern with urban mobility and occupation of public spaces has motivated significant discussion and demonstrations of the residents in our city.

Based on the utterances published in the platform forums, it is possible to observe the responsive position or co-authorship in the process of creating meaning from the video letters. The individual voices expressed in the video letters show subjective and responsible connotations, the student's voices include their individuality and at the same time the type of dialogic responsibility that influences the perception and understanding of another person's dialogues and worldviews. 
Therefore, it is possible to understand that the creative process developed by the participants in our research, include a multiplicity of contexts, which constitute the dialogic process itself (BIAZUS, 2001). Furthermore: "In the same way that a dialogical process of co-creativity is established considering comprehension, we understand that a process of co-authorship is established, as well, as a hybridization in creating while in interaction with technological devices" (BIAZUS, 2001, p. 59). The co-authorship highlighted by Biazus may be appreciated in the flow of texts in the forum after UFRGS students saw the video letters from UNT. The students from both groups discussed through short visual and verbal comments that quilted together with each following message.

\section{Final Considerations and Implications}

Access to the Internet, digital technologies, and virtual learning platforms benefit the society at large, but this widening of conditions of learning, of accessing and of exchanging also requires greater ability to select and produce coherent and stable, albeit provisory, meaning. The considerations brought by Bakhtin about the interactions between peoples' utterances, in his theory of the unfinished dialogue, and the polyphony of texts and utterances, incite us to experiment with modes of dialogue in the digital world. Bakhtin broadens and re-dimensions dialogue and polyphony towards the emergence of multiplicity of dialogic (i.e., agonistic) viewpoints and revisions the concept of interactions with the Other.

We sought in this research to broaden the dialogue between the pre-service art teachers, challenge them to create practical and innovative methodologies that incorporate the use of Information and Communication Technology (ICT), and the exchange between different subjects that constitute a geographically distant Other (in the case of this study, the students from the partner university).

We believe that experiences like this one, can contribute to studies about online education by stimulating the participants to be researchers and not merely task executors, thus exploring their human, cultural and technological potential. We can say that the opportunity to participate in the AprenDi 2.0, incited the students from both universities to search for images, sounds, expressions, languages and forms to produce meaning through verbal-audio-visual texts in the video letter narratives According to Bakhtin, before we participate in aesthetic activity, we participate first, in ethical negotiations. In this collaboration, the students become authors-creators in the process of generating the video letters and co-authorship happened when interlocutors answered responsibly or dialogically to agreements and disagreements within their own context and life and in connection to their collaborators.

Bakhtin proposes that the word lives in the encounter of the other's words. The encounters of the Brazilian professor with the U.S. students and U.S. professor with Brazilian students, a few months after the project's conclusion, promoted dialogic resonances of the others' words, discourses were updated; new meanings were built and asked for completeness. This is our aesthetic instinct, according to Bakhtin. The meaning of totality is always assigned in different ways to each subject that completes it (EMERSON, 2003).

In each encounter, between professors and students, the meaning was renewed. Images and words from the online encounters were updated and resonated with every encounter. For Bakhtin, 
and for the authors of this text, the Other is always capitalized because without her or him the $I$ does not exist.

\section{References}

AMORIM, M. O Pesquisador e seu Outro: Bakhtin nas ciências humanas. São Paulo: Ed. Musa, 2004.

AXT, M. Do Pressuposto Dialógico na Pesquisa: o lugar da multiplicidade na formação (docente) em rede. Revista Informática na Educação, v. 11, n. 01, p. 91-104, 2008.

AXT, M. Mundo da vida e pesquisa em educação: ressonâncias, implicações, replicações. Rev. de Letras de Hoje: estudos e debates de assuntos de linguística, literatura e língua portuguesa, v. 46, n. 1 , p. $46-54,2011$.

BAKHTIN, M. Estética da Criação Verbal. Translated by P. Bezerra. 6th ed. São Paulo: Martins Fontes, 2011.

BIAZUS, M.C.V. Ambientes Digitais e Processos de Criação. 2001. Doctoral dissertation - Universidade Federal do Rio Grande do Sul, 2001, Porto Alegre, BR-RS.

BOURRIAUD, N. Pós-Produção: como a arte reprograma o mundo contemporâneo. Translated by D. Bottmann. São Paulo: Martins, 2009.

CAMnitZer, L. Projeto Pedagógico da 6a Bienal do Mercosul. Porto Alegre: [s.n.], 2006.

CANCLINI, N. G. A Globalização Imaginada. Translated by S. Molina. São Paulo: Iluminuras, 2007.

EMERSON, C. Os Cem Primeiros Anos de Mikhail Bakhtin. Translated by P. Jorgensen Jr. Rio de Janeiro: DIFEL, 2003.

PÉREZ MILES, A. Dialogic Encounters: The school of Panamerican Unrest. 2011. Doctoral dissertation - The Pennsylvannia State University, 2011, State College, PA. 